\title{
The effect of understory on cation binding reactions and aluminium behaviour in acidic soils under spruce forest stands (Southern Poland)
}

\author{
Krystyna Ciarkowska (iD) Anna Miechówka
}

Received: 16 May 2018/ Accepted: 10 February 2019/Published online: 15 February 2019

(C) The Author(s) 2019

\begin{abstract}
Acidic forest soils with two dominant understories, bilberry (Vaccinium myrtillus L.) or alpine lady fern (Athyrium distentifolium Tausch ex Opiz), have been investigated to evaluate the influence of the understory on sorption properties and aluminium behaviour. We investigated acidity, cation exchange properties, organic matter content (SOM) and quality as well as $\mathrm{Al}$ bonding to organic matter in humus horizons of soils taken from two different locations. SOM was the major contributor to total cation exchange capacity $\left(\mathrm{CEC}_{\mathrm{t}}\right)$ and effective cation exchange capacity $\left(\mathrm{CEC}_{\mathrm{e}}\right)$, and a strong relationship was found between SOM and both $\mathrm{CEC}_{t}$ and $\mathrm{CEC}_{\mathrm{e}}$, independently of the understory and location. SOM differed in quality, having more fulvic acids in soils under bilberry than in soils under alpine lady fern. For that reason, SOM in soils under bilberry complexed more $\mathrm{Al}$ in the exchangeable form in the soluble fulvic acid fraction such that they could be easily washed out, while in soils under alpine lady fern aluminium was mainly bound more stably. We also found that the chemical character of $\mathrm{Al}$ depended on the understory
\end{abstract}

Responsible Editor: Jonathan Sanderman.

K. Ciarkowska $(\bowtie) \cdot$ A. Miechówka

Soil Science and Soil Protection Department, Institute of Soil Science and Agrophysics, University of Agriculture in Krakow, Aleja Mickiewicza 21, 31-120 Kraków,

Poland

e-mail: rrciarko@cyf-kr.edu.pl type. In soils under bilberry the relation between base saturation and $\mathrm{pH}$ could be successfully modelled by a modified Henderson-Hasselbalch equation when Al was considered as a base cation, which is typical for forest podzols. However, in soils under alpine lady fern, this model was efficient only when $\mathrm{Al}$ was treated as an acid cation. We concluded that alpine lady fern as the main understory species reduces solubility and potential toxicity of aluminium, thus significantly affecting soil biogeochemistry.

Keywords Bilberry · Alpine lady fern - Aluminium · Fulvic acids $\cdot$ Sorption properties

\section{Introduction-theoretical background and assumptions}

It is assumed that in humus horizons, cation binding is regulated primarily by soil organic matter (SOM) and to a lesser extent it occurs on the surfaces of some clay minerals (Blaser et al. 2008; James et al. 2016). Under acidic conditions the principal functional groups of SOM involved in these reactions are the acidic carboxyl and hydroxyl groups of SOM, which dissociate protons at a $\mathrm{pH}$ of about 3 . In this way, negatively charged sites are formed for which $\mathrm{Al}$ and protons compete, determining soil $\mathrm{pH}$ values and Al solubility (Skyllberg 1999). Al cations interact with SOM by 
neutralizing the electrical charge on organic molecular surfaces through both weak and strong binding processes (Huang 1988; Li et al. 2016). In such conditions the most effective SOM compounds taking part in cation exchange reactions (weak binding) are fulvic acids (FAs), which exhibit higher total acidity values than humic acids (HAs) (Tan 2005).

Hence, in forest soils the amount and quality of SOM greatly modifies the nature of soil acidity, but soil acidity and complexation of metals to SOM may also affect the stability of organic matter (Arbestain et al. 2003; Berggren and Mulder 1995; Mulder et al. 2001). Mueller et al. (2012) confirmed this conception from their study on the influence of tree species on carbon stocks and acidity in mineral soils in a common garden experiment. According to them, the link between SOM and acidity operates in two directions. An amount of SOM contributes to variation in total acidity by providing exchange sites for protons, $\mathrm{Al}$ and Fe ions, and/or the amount of soil acidity contributes to variation in SOM through cation-bridging or other constraints on microbial decomposition of SOM.

In acidic forest soils, aluminium occurs in high amounts in compounds that when hydrolysing produce $\mathrm{Al}^{+3}, \mathrm{AlOH}^{+}$or $\mathrm{Al}(\mathrm{OH})_{2}^{2+}$ cations (Skyllberg 1999). On theoretical grounds, Mulder et al. (2001) and Mueller et al. (2012) defined the $\mathrm{pH}_{\text {threshold }}$, that is, the soil $\mathrm{pH}$ below which $\mathrm{Al}(\mathrm{OH})_{3}$ is unstable and $\mathrm{pH}$ is controlled by chemisorption of $\mathrm{Al}$ to soil organic matter. According to Gruba et al. (2013), $\mathrm{pH}_{\text {threshold }}$ can be estimated for any acidic soil by the following equation:

$\mathrm{pH}_{\text {threshold }}=6.06-0.47 \mathrm{pH}_{\mathrm{KCl}}$

Binkley and Giardina (1998) attributed the impact of forest stands on soil acidity to the acid litter input to the soil and to the apparent dissociation constant $\left(\mathrm{K}_{\mathrm{app}}\right)$ of soil organic acids. The $\mathrm{K}_{\mathrm{app}}$ value differs due to differences in the functional groups of SOM derived from different forest tree species. In acidic, organic matter-rich forest soils the value of $\mathrm{pH}$ solution can be described by the Henderson-Hasselbach equation, which after the modification of Bloom and Grigal (1985) takes the following form:

$\mathrm{pH}=\mathrm{pK}_{\mathrm{app}}+\mathrm{nLog}\left[\left(\mathrm{BS}_{\mathrm{e}} / 1-\mathrm{BS}_{\mathrm{e}}\right)\right]$,

where $\mathrm{pK}_{\mathrm{app}}$ stands for the negative logarithm of the apparent dissociation constant, $\mathrm{n}$ is an empirical stoichiometric constant of the reaction, $\mathrm{BS}_{\mathrm{e}}$ is the effective base saturation, i.e. the fraction of the effective cation exchange capacity $\left(\mathrm{CEC}_{\mathrm{e}}\right)$ neutralized by base cations $\left(\mathrm{Ca}^{2+}, \mathrm{Mg}^{2+}, \mathrm{K}^{+}, \mathrm{Na}^{+}\right)$. Thus, $1-\mathrm{BS}_{\mathrm{e}}$ refers to the fraction of exchangeable acidity $\left(\mathrm{H}_{\mathrm{e}}+\mathrm{Al}_{\mathrm{e}}\right)$.

As shown above, the effect of tree species composition on $\mathrm{pH}$ value regulation, cation binding properties, Al solubility and their relations with SOM in acidic forest soils has already been extensively investigated in acidic soils of different regions such as: Scandinavia (Skyllberg 1999; Skyllberg et al. 2001), northern USA (Johnson 2002; Mueller et al. 2012), Brazil (Abreu et al. 2003) and Poland (Gruba and Mulder 2008, 2015). However, to our knowledge the effect of understory type on such parameters and their relationships has not been considered yet.

Since it has already been ascertained that the type of forest understory (domination of Alpine lady fern or bilberry) affects the course of pedogenic processes as expressed by the quality of humus and the mobility of $\mathrm{Fe}$ and $\mathrm{Al}$ within the soil profiles of the Carpathian subalpine spruce forest stands (Ciarkowska and Miechówka 2017), one can suppose that the understory type also affects cation binding properties and the behaviour of aluminium in these soils. The aim of this work was to verify this hypothesis by: (i) determining relationships between parameters describing cation exchange properties at sites with the different understories and locations, (ii) evaluating the role of $\mathrm{SOM}$ in cation binding properties and $\mathrm{pH}$ regulation, as well as (iii) comparing the share of $\mathrm{Al}$ forms with different solubilities in top mineral horizons of acidic spruce forest soils with bilberry (Vaccinium myrtillus L.) or alpine lady fern (Athyrium distentifolium Tausch ex Opiz) as the dominant understory. An understanding of the solubility of aluminium in acidic soils may also be important in predicting the amount of toxic $\mathrm{Al}$ that is present in soils.

\section{Study area and sampling}

The investigations were carried out in Beskid Żywiecki Mts. (N $49^{\circ} 34^{\prime}-37^{\prime}$, S $19^{\circ} 29^{\prime}-37^{\prime}$ ) and in the Gorce Mts. ( $\mathrm{N} 49^{\circ} 32^{\prime}$, S $20^{\circ} 09-8^{\prime}$ ), which are both situated in the West Carpathian Mountain Range (Southern Poland). They are located in the cool climatic zone, with a mean annual temperature from 
+4 to $+2{ }^{\circ} \mathrm{C}$. The mean annual rainfall measured at the Markowe Szczawiny weather station (Beskid Żywiecki, northern slopes of Babia Góra Mt. $1180 \mathrm{~m}$ a.s.l.) is $1490 \mathrm{~mm}$ (Obrębska-Starkel 2004) and at the Turbacz weather station (Gorce, northern slopes of Turbacz Mt. $1310 \mathrm{~m}$ a.s.l.) $1290 \mathrm{~mm}$ (Miczyński 2006).

In Beskid Żywiecki, all research areas were situated in the Babia Gora range at the altitude of 1090-1370 m a.s.l., on northern slopes of Cyl Mt. (1515 m a.s.1.), Diablak Mt. (1725 m a.s.l.), Sokolica Mt. (1367 m a.s.1.) and Polica Mt. (1369 m a.s.1.). The Gorce Mts. research areas were situated on the northern slope ridge extending to the east between Turbacz Mt. (1310 $\mathrm{m}$ a.s.1.) and Jaworzyna Mt. (1288 $\mathrm{m}$ a.s.l.) at the altitude of $1205-1250 \mathrm{~m}$ a.s.l. Slope exposures of the research areas ranged from 15 to $25^{\circ}$. These mountain ranges are representative for the Outer West Carpathians in terms of their ecology and landscapes, in which the natural ecosystems, especially acidic spruce forest of the upper montane belt, have survived relatively well. Both the Beskid Żywiecki and Gorce mountain ranges are built from the Magura nappe, which in the area of Poland is the biggest nappe and the most internal one of the Outer Carpathians (Cieszkowski 2006).

Studied soils were derived from the Upper Cretaceous and Paleogene flysch rocks of the Magura Nappe, in Gorce from Krynica subunit (sandstones of Magura or Szczawnica formations), while in Beskid Żywiecki from the Raczańska subunit. All sites are covered by spruce forests (Plagiothecio-Piceetum association) with bilberry (V. myrtillus) or alpine lady fern (A. distentifolium) as the main understory species (Loch 2002; Parusel et al. 2004). Soils with alpine lady fern as the dominant understory (referred to here as fern soils) were Dystric Skeletic Cambisols; soils with bilberry prevalent in the understory (referred to here as bilberry soils) were Skeletic Podzols (WRB, IUSS Working Group 2015). Detailed morphology of the studied soils is given in Ciarkowska and Miechówka (2017). Also, in our study we included soils that did not have bilberry or alpine lady fern as understory species (or only a very small amount present), which we used as reference soils. Such soils occurred on much smaller areas than bilberry or fern soils, on the edges of occurrences of fern or bilberry soils.
Reference soils were either Dystric Skeletic Cambisols or Skeletic Podzols (WRB, IUSS Working Group 2015).

In each location, Gorce and Beskid Żywiecki, we selected six research areas of about $100 \mathrm{~m}^{2}$ each with uniform vegetation (three with Alpine lady fern and three with bilberry as the dominant understory) separated by several meters. With the use of an auger, systematic sampling was done every $10 \mathrm{~m}$, and 10 soil samples were collected from top mineral horizons (A or AE) from each research area, which resulted in 60 samples each of fern soils and bilberry soils. As soils without bilberry or Alpine lady fern (or with a small amount of them) in understory occurred rather rarely we found three areas of about $10 \mathrm{~m}^{2}$ from which we took 10 soil samples altogether.

\section{Laboratory methods}

Analyses were performed on air dried soil samples sieved with a $2 \mathrm{~mm}$ sieve. The $\mathrm{pH}$ values were established potentiometrically in distilled $\mathrm{H}_{2} \mathrm{O}$ and in a $1 \mathrm{M} \mathrm{KCl}$ suspension with a soil:extractant ratio of 1:2.5. Clay content was determined according to the hydrometer method (Tan 2005).

Organic carbon content $\left(\mathrm{C}_{\mathrm{t}}\right)$ was determined through the Walkley-Black wet combustion method with the use of a $0.1 \mathrm{M} \mathrm{K}_{2} \mathrm{Cr}_{2} \mathrm{O}_{7}$ solution with a concentrated $\mathrm{H}_{2} \mathrm{SO}_{4}$ addition. Measured $\mathrm{C}_{\mathrm{t}}$ contents were converted into organic matter (SOM) using a coefficient of 1.724 (Tan 2005).

Humic acids (HAs) and fulvic acids (FAs) were extracted by centrifugation of soil samples with $1 \mathrm{M}$ $\mathrm{NaOH}$, as recommended by the International Humic Substance Society (IHSS; Calderoni and Schnitzer 1984). In the collected supernatant, the sum of total HAs and FAs was obtained. HAs were separated from the precipitate by its acidification to $\mathrm{pH} 1$. The $\mathrm{C}$ content in fractions was determined via the WalkleyBlack wet combustion method.

Exchangeable $\mathrm{Ca}, \mathrm{Mg}, \mathrm{K}$ and $\mathrm{Na}$ was determined by extraction with $1 \mathrm{M} \mathrm{NH}_{4} \mathrm{OAc}(\mathrm{pH} 7)$ and evaluation with a Perkin-Elmer atomic emission spectrometer ICP-OES Optima 7300 DV, and multi-element ICP-IV Merck standard solution. Exchangeable acidity, taken as the sum of exchangeable $\mathrm{H}^{+}\left(\mathrm{H}_{\mathrm{e}}\right)$ and exchangeable $\mathrm{Al}^{3+}\left(\mathrm{Al}_{\mathrm{e}}\right)$, was determined by 
extraction with by $1 \mathrm{M} \mathrm{KCl}$ and then titration with $1 \mathrm{M} \mathrm{NaOH} ; \mathrm{Al}_{\mathrm{e}}$ was determined by back-titrating the filtrate after $\mathrm{Al}$ neutralization with $1 \mathrm{M} \mathrm{KF}$ and $\mathrm{H}_{\mathrm{e}}$ calculated as a difference between exchangeable acidity and $\mathrm{Al}_{\mathrm{e}}$ (Tan 2005).

Total acidity $\left(\mathrm{T}_{\mathrm{A}}\right)$ was determined using $1 \mathrm{M}$ $\mathrm{Ca}\left(\mathrm{CH}_{3} \mathrm{COO}\right)_{2}$ in a 1:2.5 soil/solution ratio. Suspensions were shaken for $1 \mathrm{~h}$, filtered and titrated with $0.1 \mathrm{M} \mathrm{NaOH}$ to $\mathrm{pH}$ 8.2. The total acidity was calculated from the amount of base used (Ostrowska et al. 1991). $\mathrm{Al}\left(\mathrm{Al}_{\mathrm{t}}\right)$ extracted with $0.1 \mathrm{M} \mathrm{Na}_{2} \mathrm{P}_{2} \mathrm{O}_{7}$ at $\mathrm{pH}=10$, was treated as total Al.

On the basis of the determined parameters, the following calculations and designations were made:

Sum of exchangeable cations $\left(\mathrm{cmol}_{\mathrm{c}} \mathrm{kg}^{-1}\right): \mathrm{BC}$

$$
=\mathrm{Ca}^{2+}+\mathrm{Mg}^{2+}+\mathrm{K}^{+}+\mathrm{Na}^{+}
$$

Cation exchange capacity $\left(\mathrm{cmol}_{\mathrm{C}} \mathrm{kg}^{-1}\right): \mathrm{CEC}_{\mathrm{t}}$

$=\mathrm{BC}+\mathrm{T}_{\mathrm{A}}$

Effective cation exchange capacity $\left(\mathrm{cmol}_{\mathrm{c}} \mathrm{kg}^{-1}\right)$ :

$$
\mathrm{CEC}_{\mathrm{e}}=\mathrm{BC}+\mathrm{H}_{\mathrm{e}}+\mathrm{Al}_{\mathrm{e}}
$$

Saturation with basic cations $\left(\mathrm{cmol}_{\mathrm{c}} \mathrm{kg}^{-1}\right)$ : BS

$$
=\mathrm{BC} / \mathrm{CEC}_{\mathrm{t}}
$$

Organic (residual) aluminium $\left(\mathrm{cmol}_{\mathrm{C}} \mathrm{kg}^{-1}\right): \mathrm{Al}_{\mathrm{org}}$ $=\mathrm{Al}_{\mathrm{t}}-\mathrm{Al}_{\mathrm{e}}$

Organic (residual) hydrogen $\left(\mathrm{cmol}_{\mathrm{c}} \mathrm{kg}^{-1}\right): \mathrm{H}_{\mathrm{org}}$ $=\mathrm{H}_{\mathrm{t}}-\mathrm{H}_{\mathrm{e}}$

Total hydrogen $\left(\mathrm{cmol}_{\mathrm{c}} \mathrm{kg}^{-1}\right): \mathrm{H}_{\mathrm{t}}=\mathrm{T}_{\mathrm{A}}-\mathrm{Al}_{\mathrm{t}}$

\section{Statistical analysis}

The parameters of the studied soils were presented as the arithmetic means with standard deviations (SD). A one-way ANOVA was used to determine the differences in the examined parameters among the studied soils grouped according to the understory cover and location. Prior to the variance analysis, it was verified whether the tested variables were normally distributed (Shapiro-Wilk testing) and if there was a homogeneity of variance (Levene test). Owing to the presence of a normal distribution, parametric variance analysis could be applied. In order to estimate the least significant differences between the mean values of homogenous groups, a Bonferroni post hoc correction was employed (at $\mathrm{p}<0.05$ ).

Relationships between variables were investigated by performing correlation and regression analyses. We used the Pearson product-moment correlation coefficient (r) to measure the degree of linear association between variables. With the use of principal component analysis (PCA), the relationship between the examined variables (selected soil parameters) and soils of different sites was presented. Plotting of soil parameters in PC1-PC2 space allowed us to specify which parameters affected cation binding properties of the surface horizons under different understories and the direction of the effect (ter Braak and Smilauer 2012). Statistical analyses were conducted using Statistica PL v 12 packet (StatSoft Inc., 2014, Poland) and Canoco 5 (ter Braak and Smilauer 2012).

\section{Results}

Parameters related to cation exchange properties

Humus horizons of all studied soils were of sandy loam or loamy sand textures with similar mean clay contents (9-11\%), except for soils in Gorce under bilberry (BG) where the amount of clay was lower than in other soil samples (Table 1). Mean $\mathrm{pH}_{\mathrm{H} 2 \mathrm{O}}$ was almost the same in all soil groups, around 3.8-3.9, while $\mathrm{pH}_{\mathrm{KCl}}$ was higher in reference soils (Ref) and in soils under fern (both at 3.0) than under bilberry (2.8) independently of the location. The threshold value of $\mathrm{pH}$ (see Eq. 1) ranged between 4.61 in fern soils in Gorce (FG), 4.66 in Ref soils, 4.70 in fern soils in Beskid Żywiecki (FB) and 4.74 in bilberry soils both in Gorce (BG) and Beskid Żywiecki (BB); thus, the pH of all soils was below $\mathrm{pH}_{\text {threshold} \text {. }}$.

Mean SOM content was higher in A horizons under fern (76.57 and $80.28 \mathrm{~g} \mathrm{~kg}^{-1}$ in FG and FB, respectively) than in $\mathrm{AE}$ or A horizons of the Ref soils (69.86 $\mathrm{g} \mathrm{kg}^{-1}$ ) or the $\mathrm{AE}$ horizons of soils under bilberry $\left(61.75 \mathrm{~g} \mathrm{~kg}^{-1}\right.$ in $\mathrm{BG}$ and $67.37 \mathrm{~g} \mathrm{~kg}^{-1}$ in $\mathrm{BB})$. The share of fulvic acids in SOM (\% FA) was statistically lower under fern (about 36\%) than in soils under bilberry (more than $40 \%$ ) in both locations, 
Table 1 Characteristics of analysed and calculated soil parameters (arithmetic mean \pm SD)

\begin{tabular}{|c|c|c|c|c|c|}
\hline \multirow[t]{2}{*}{ Parametres } & \multirow[t]{2}{*}{ Referential soils (Ref) } & \multicolumn{2}{|l|}{ Gorce } & \multicolumn{2}{|l|}{ Beskid Zywiecki } \\
\hline & & Fern soils $(\mathrm{FG})$ & Bilberry soils (BG) & Fern soils $(\mathrm{FB})$ & Bilberry soils (BB) \\
\hline Clay & $9.4^{\mathrm{b}} \pm 2.9$ & $11.0^{\mathrm{b}} \pm 2.1$ & $5.00^{\mathrm{a}} \pm 1.0$ & $10.0^{\mathrm{b}} \pm 2.0$ & $9.0^{\mathrm{b}} \pm 1.5$ \\
\hline $\mathrm{pH}_{\mathrm{H} 2 \mathrm{O}}$ & $3.88^{\mathrm{a}} \pm 0.33$ & $3.90^{\mathrm{a}} \pm 0.42$ & $3.89^{\mathrm{a}} \pm 0.18$ & $3.89^{\mathrm{a}} \pm 0.17$ & $3.83^{\mathrm{a}} \pm 0.19$ \\
\hline $\mathrm{pH}_{\mathrm{KCl}}$ & $2.99^{b} \pm 0.35$ & $3.09^{b} \pm 0.51$ & $2.81^{\mathrm{a}} \pm 0.14$ & $2.92^{b} \pm 0.23$ & $2.82^{\mathrm{a}} \pm 0.12$ \\
\hline $\mathrm{pH}_{\text {treshold }}$ & $4.60^{\mathrm{a}} \pm 0.20$ & $4.61^{\mathrm{a}} \pm 0.21$ & $4.74^{\mathrm{b}} \pm 0.07$ & $4.65^{\mathrm{a}} \pm 0.11$ & $4.74^{\mathrm{b}} \pm 0.06$ \\
\hline $\mathrm{SOM}$ & $69.86^{\mathrm{ab}} \pm 22.34$ & $76.57^{\mathrm{ab}} \pm 18.78$ & $61.75^{\mathrm{a}} \pm 15.24$ & $80.28^{\mathrm{b}} \pm 11.87$ & $67.37^{\mathrm{ab}} \pm 16.83$ \\
\hline FA & $38.68^{\mathrm{ab}} \pm 8.52$ & $35.80^{\mathrm{a}} \pm 7.58$ & $40.83^{b} \pm 4.69$ & $36.59^{\mathrm{a}} \pm 6.16$ & $42.24^{\mathrm{b}} \pm 5.47$ \\
\hline $\mathrm{CEC}_{\mathrm{e}}$ & $10.54^{\mathrm{a}} \pm 5.45$ & $13.96^{\mathrm{b}} \pm 2.94$ & $10.05^{\mathrm{a}} \pm 3.06$ & $15.66^{\mathrm{c}} \pm 1.79$ & $12.85^{\mathrm{b}} \pm 3.58$ \\
\hline $\mathrm{CEC}_{\mathrm{t}}$ & $20.10^{\mathrm{ab}} \pm 5.12$ & $29.85^{\mathrm{c}} \pm 4.57$ & $16.10^{\mathrm{a}} \pm 3.77$ & $31.36^{\mathrm{c}} \pm 2.50$ & $17.61^{\mathrm{a}} \pm 4.41$ \\
\hline $\mathrm{H}_{\mathrm{t}}$ & $10.26^{\mathrm{ab}} \pm 2.51$ & $16.34^{\mathrm{c}} \pm 0.94$ & $6.44^{\mathrm{a}} \pm 1.16$ & $15.88^{\mathrm{c}} \pm 1.04$ & $6.88^{\mathrm{a}} \pm 1.09$ \\
\hline $\mathrm{Al}_{\mathrm{t}}$ & $8.51^{\mathrm{a}} \pm 1.52$ & $13.09^{\mathrm{b}} \pm 3.28$ & $9.92^{\mathrm{a}} \pm 1.03$ & $16.33^{\mathrm{c}} \pm 3.38$ & $9.82^{\mathrm{a}} \pm 0.89$ \\
\hline $\mathrm{BC}$ & $1.13^{b} \pm 0.22$ & $1.04^{\mathrm{b}} \pm 0.13$ & $0.54^{\mathrm{a}} \pm 0.11$ & $1.19^{\mathrm{b}} \pm 0.17$ & $0.49^{\mathrm{a}} \pm 0.12$ \\
\hline
\end{tabular}

Clay amount \%, SOM soil organic matter $\left(\mathrm{gkg}^{-1}\right), F A$ fulvic acids share in SOM (\%), $H_{\mathrm{t}}, A l_{\mathrm{t} \text { : }}$ total hydrogen and aluminium, $C E C_{\mathrm{e}}$, $C E C_{\mathrm{t}}$ effective and total cation exchange capacity, $B C$ basic cations $\left(\mathrm{Ca}^{2+}+\mathrm{Mg}^{2+}+\mathrm{K}^{+}+\mathrm{Na}^{+}\right), \mathrm{H}_{\mathrm{t}}, \mathrm{Al}_{\mathrm{t}}, \mathrm{CEC}_{\mathrm{e}}, \mathrm{CEC} \mathrm{C}_{\mathrm{t}}$ and $\mathrm{BC}$ are given in ${ }_{\mathrm{c}} \mathrm{mol}^{+} \mathrm{kg}^{-1}$

while in Ref soils the share of FA was in between the fulvic acid share of the fern and bilberry soils (Table 1).

Effective cation exchange capacity values $\left(\mathrm{CEC}_{\mathrm{e}}\right)$ were diversified according to understory and location, being the highest in FB $\left(15.66 \mathrm{cmol}_{\mathrm{c}} \mathrm{kg}^{-1}\right)$ and the lowest in BG and Ref (10.05 and $10.54 \mathrm{cmol}_{\mathrm{c}} \mathrm{kg}^{-1}$, respectively). In bilberry soils, total CEC values $\left(\mathrm{CEC}_{\mathrm{t}}\right)$ amounted to 16.1 and $17.61 \mathrm{cmol}_{\mathrm{c}} \mathrm{kg}^{-1}$, respectively for $\mathrm{GB}$ and $\mathrm{BB}$. In soils under fern, $\mathrm{CEC}_{\mathrm{t}}$ values were significantly larger than in bilberry soils, about $30 \mathrm{cmol}_{\mathrm{C}} \mathrm{kg}^{-1}$ both in FG and FB, while in Ref soils the $\mathrm{CEC}_{\mathrm{t}}$ value was in between the values of the fern and bilberry soils. Thus, soils rich in SOM had also high $\mathrm{CEC}_{\mathrm{e}}$ and $\mathrm{CEC}_{\mathrm{t}}$. The $\mathrm{CEC}_{\mathrm{t}} / \mathrm{C}_{\mathrm{t}}$ ratio was significantly larger for fern soils $\left(0.67 \mathrm{cmol}_{\mathrm{c}} \mathrm{g}^{-1} \mathrm{C}\right.$ for both FG and FB) than for Ref soils $\left(0.51 \mathrm{cmol}_{\mathrm{c}} \mathrm{g}^{-1} \mathrm{C}\right)$ and bilberry ones $\left(0.45 \mathrm{cmol}_{\mathrm{c}} \mathrm{g}^{-1} \mathrm{C}\right.$ for both $\mathrm{BG}$ and $\mathrm{BB}) . \mathrm{CEC}_{\mathrm{e}}$ constituted about $50 \%$ of $\mathrm{CEC}_{\mathrm{t}}$ in fern and Ref soils and significantly more in bilberry soils, $73 \%$ in BB and $63 \%$ in BG. The sum of basic cations was higher in Ref soils and in soils under fern than under bilberry, independently of the location. $\mathrm{BC}$ in the A horizons of fern soils and in the A or AE horizons of Ref soils exceeded $1 \mathrm{cmol}_{\mathrm{c}} \mathrm{kg}^{-1}$ and it was about 0.5 $\mathrm{cmol}_{\mathrm{c}} \mathrm{kg}^{-1}$ in AE horizons of bilberry soils (Table 1).
Share of cations in total CEC

Total hydrogen content $\left(\mathrm{H}_{\mathrm{t}}\right)$, composed of organic $\left(\mathrm{H}_{\text {org }}\right)$ and effective (exchangeable) $\mathrm{H}\left(\mathrm{H}_{\mathrm{e}}\right)$, was much lower in bilberry soils (i.e. did not exceed $7 \mathrm{cmol}_{\mathrm{c}}$ $\mathrm{kg}^{-1}$ ) than in fern soils (about $16 \mathrm{cmol}_{\mathrm{c}} \mathrm{kg}^{-1}$ ) in both locations (Beskid Żywiecki and Gorce), while in Ref soils its value amounted to about $10 \mathrm{cmol}_{\mathrm{c}} \mathrm{kg}^{-1}$. Independently of the understory, $\mathrm{H}_{\text {org }}$ prevailed over $\mathrm{H}_{\mathrm{e}}$, but the prevalence of $\mathrm{H}_{\text {org }}$ was much lower in bilberry soils (twofold) than in fern (threefold) and especially in Ref soils where $\mathrm{H}_{\text {org }}$ prevailed over $\mathrm{H}_{\mathrm{e}}$ about ninefold (Fig. 1a, b).

In both locations, total aluminium content $\left(\mathrm{Al}_{\mathrm{t}}\right)$ was also lower in bilberry soils than in fern soils, with higher values in $\mathrm{FB}$ (exceeding $16{ }_{\mathrm{c}} \mathrm{mol} \mathrm{kg}{ }^{-1}$ ) than in FG $\left(13 \mathrm{cmol}_{\mathrm{c}} \mathrm{kg}^{-1}\right) . \mathrm{Al}_{\mathrm{t}}$ content in Ref soils was similar to its content in bilberry soils. In bilberry soils, regardless of the location, the share of exchangeable $\mathrm{Al}\left(\mathrm{Al}_{\mathrm{e}}\right)$ was about four times higher than organic $\mathrm{Al}$ $\left(\mathrm{Al}_{\text {org }}\right)$, while in fern soils the shares of $\mathrm{Al}_{\text {org }}$ and $\mathrm{Al}_{\mathrm{e}}$ depended on the location. In FB there were almost equal amounts of $\mathrm{Al}_{\mathrm{e}}$ and $\mathrm{Al}_{\text {org }}$ (about $8 \mathrm{cmol}_{\mathrm{c}} \mathrm{kg}^{-1}$ ), while in $\mathrm{FG}, \mathrm{Al}_{\mathrm{e}}$ share was about twice as high as $\mathrm{Al}_{\text {org }}, 8.4$ and $4.7 \mathrm{cmol}_{\mathrm{c}} \mathrm{kg}^{-1}$, respectively. In Ref soils there were similar amounts of $\mathrm{Al}_{\mathrm{e}}\left(8.26 \mathrm{cmol}_{\mathrm{c}}\right.$ $\mathrm{kg}^{-1}$ ) and $\mathrm{Al}_{\text {org }}\left(6.31 \mathrm{cmol}_{\mathrm{c}} \mathrm{kg}^{-1}\right.$ ) (Fig. 1c, d). 

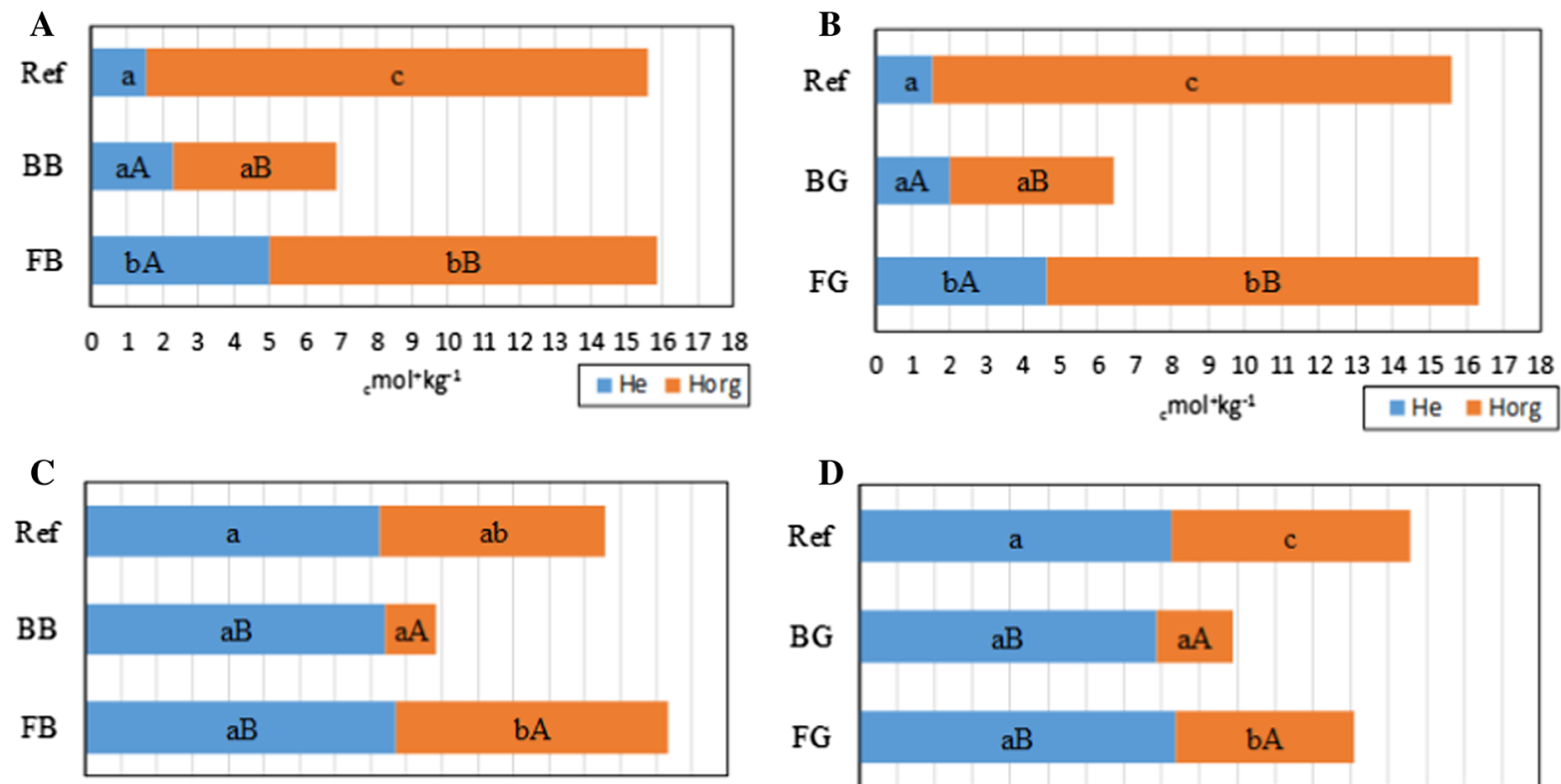

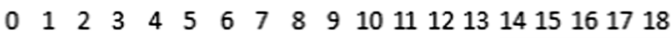
${ }_{\mathrm{i}} \mathrm{mol}^{+} \mathrm{kg}^{-1} \quad$ Ale $=$ Alorg

Fig. 1 Share of exchangeable hydrogen $\left(\mathrm{H}_{\mathrm{e}}\right)$ and organic hydrogen $\left(\mathrm{H}_{\text {org }}\right)$ in total hydrogen $\left(\mathrm{H}_{\mathrm{t}}\right)$ : a Beskid Żywiecki, b Gorce, share of exchangeable aluminium $\left(\mathrm{Al}_{\mathrm{e}}\right)$ and organic

The ratios of $\mathrm{H}_{\mathrm{e}} / \mathrm{CEC}_{\mathrm{t}}, \mathrm{Al}_{\mathrm{e}} / \mathrm{CEC}_{\mathrm{t}}$ and $\mathrm{BC} / \mathrm{CEC}_{\mathrm{t}}$ were arranged in the same order: $\mathrm{BC}_{\mathrm{CEC}}$ $(0.03-0.06)<\mathrm{H}_{\mathrm{e}} / \mathrm{CEC}_{\mathrm{t}} \quad(0.08-0.16)<\mathrm{Al}_{\mathrm{e}} / \mathrm{CEC}_{\mathrm{t}}$ $(0.28-0.51)$ in all studied soils. $\mathrm{H}_{\mathrm{e}} / \mathrm{CEC}_{\mathrm{t}}$ ratios were similar in fern and bilberry soils but lower in Ref soils, while $\mathrm{Al}_{\mathrm{e}} / \mathrm{CEC}_{\mathrm{t}}$ and $\mathrm{BC} / \mathrm{CEC}_{\mathrm{t}}$ differed according to the dominant understory. In fern soils there was about a 30\% higher share of $\mathrm{BC}$ and about a twofold lower share of $\mathrm{Al}_{\mathrm{e}}$ in $\mathrm{CEC}_{\mathrm{t}}$ than in bilberry soils. In Ref soils, the $\mathrm{Al}_{\mathrm{e}} / \mathrm{CEC}_{\mathrm{t}}$ ratio ranged in between bilberry and fern soils, while the $\mathrm{BC} / \mathrm{CEC}_{\mathrm{t}}$ ratio was the highest, i.e. twofold higher than in bilberry and 1.5-fold higher than in fern soils (Fig. 2a, b).

\section{Discussion}

Relationships between parameters describing cation exchange properties and understory species

The first component from PCA analysis, PC1, explained $90.9 \%$ of variance and could be interpreted as the understory effect on cation binding properties in the studied soils (Fig. 3a). High values of highly

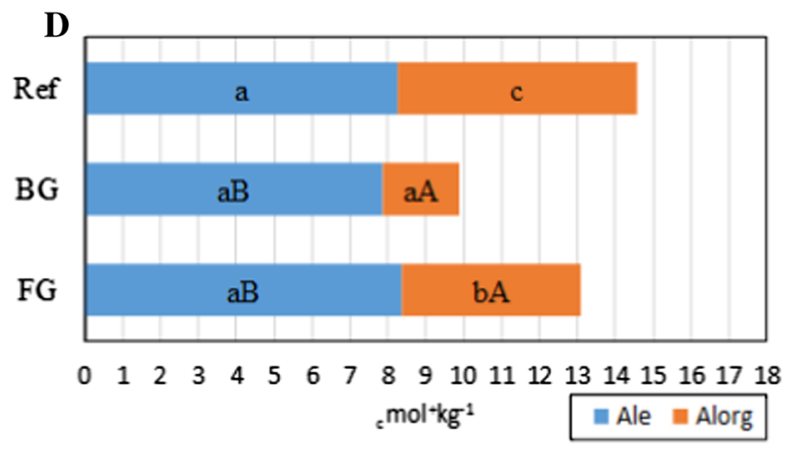

aluminium $\left(\mathrm{Al}_{\text {org }}\right)$ in total aluminium $\left(\mathrm{Al}_{\mathrm{t}}\right)$, c Beskid Żywiecki, d Gorce in soils under Alpine lady fern and bilberry compared to reference soils (Ref)

correlated parameters, such as $\mathrm{pH}, \mathrm{CEC}_{\mathrm{e}}, \mathrm{CEC}_{\mathrm{t}}, \mathrm{Al}_{\mathrm{org}}$, $\mathrm{H}_{\text {org }}, \mathrm{H}_{\mathrm{t}} / \mathrm{CEC}_{\mathrm{t}}, \mathrm{H}_{\mathrm{e}} / \mathrm{CEC}_{\mathrm{t}}, \mathrm{BC}, \mathrm{SOM}$ and clay, shaped the properties of fern soils (FB and FG). Whereas soil properties under bilberry cover $(\mathrm{BB}$ and $\mathrm{BG})$ were influenced by higher $\mathrm{FA}$ values and $\mathrm{Al}_{\mathrm{e}} / \mathrm{CEC}_{\mathrm{t}}, \mathrm{Al}_{\mathrm{t}} /$ $\mathrm{CEC}_{\mathrm{t}}$ and $\mathrm{CEC}_{\mathrm{e}} / \mathrm{C}_{\mathrm{t}}$ ratios. PC2, which explained only $8.0 \%$ of variance, seemed to divide the soils according to their differences in clay contents. It suggested a closer similarity of fern soils (FG and FB) than bilberry soils (BG and BB).

Moreover, the discrimination between sites at Beskid Zywiecki (FB vs. BB) could be explained by the $\mathrm{pH} \mathrm{H}_{2} \mathrm{O}$ vector, while the discrimination between two sites at Gorce (FG vs. BG) could be explained by the $\mathrm{pH} \mathrm{KCl}$ vector. $\mathrm{BG}$ and $\mathrm{FG}$ differed more in $\mathrm{pH}_{\mathrm{KCl}}$ values than $\mathrm{BB}$ and $\mathrm{FB}$. The difference in $\mathrm{pH}_{\mathrm{KCl}}$ values between $\mathrm{BG}$ and $\mathrm{FG}$ were caused by the difference in the sorption complex, which resulted from the much higher SOM and clay content and thus $\mathrm{CEC}_{\mathrm{e}}$ values in $\mathrm{FG}$ than in BG soils (Table 1). Whereas, between FB and BB soils the differences in these values were smaller, thus the relationship between understory and soils in Beskid Zywiecki was 

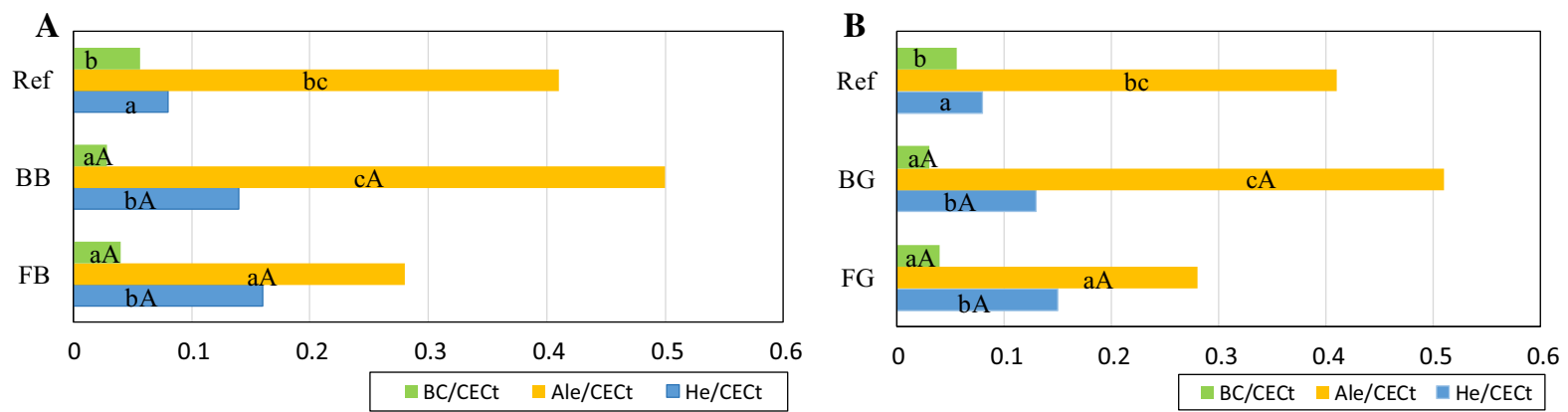

Fig. 2 Share of basic cations $(B C)$, exchangeable aluminium $\left(\mathrm{Al}_{\mathrm{e}}\right)$ and exchangeable hydrogen $\left(\mathrm{H}_{\mathrm{e}}\right)$ in total cation exchange capacity $\left(\mathrm{CEC}_{\mathrm{t}}\right)$ according to location: a Beskid Żywiecki, b Gorce in soils under Alpine lady fern and bilberry compared to reference soils (Ref)

A

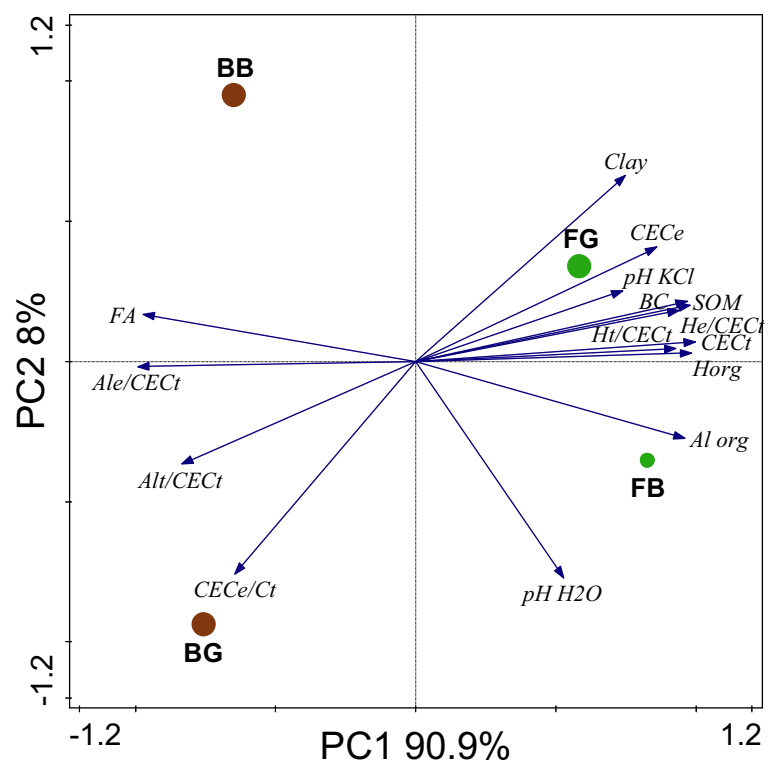

Fig. 3 Principal component analysis (PCA) showing the relationship between the examined variables (selected soil parameters) and humus horizons of soils of different understory (a) and with Ref soils included (b). In PCA following soil parameters were included: clay, $\mathrm{pH}_{\mathrm{H} 2 \mathrm{O}}, \mathrm{pH}_{\mathrm{KCl}}$, organic aluminium $\left(\mathrm{Al}_{\mathrm{org}}\right)$ and hydrogen $\left(\mathrm{H}_{\mathrm{org}}\right)$, soil organic matter (SOM), \% of fulvic acids in SOM (FA), basic cations (BC),

better expressed by the ions that were not connected with sorption complex $\left(\mathrm{pH}_{\mathrm{H} 2 \mathrm{O}}\right)$.

In BB soils, which had a comparable clay content to fern soils, cation exchanging properties were probably a little more affected by the mineral content than BG soils. For this reason, the effect of the parameters (FA, $\mathrm{Al}_{\mathrm{e}} / \mathrm{CEC}_{\mathrm{t}}, \mathrm{Al}_{\mathrm{t}} / \mathrm{CEC}_{\mathrm{t}}$ and $\left.\mathrm{CEC}_{\mathrm{t}} / \mathrm{C}_{\mathrm{t}}\right)$ appeared to be weaker in $\mathrm{BB}$ than in $\mathrm{BG}$ soils. Our results supported the study of Gruba et al. (2013), who emphasized that

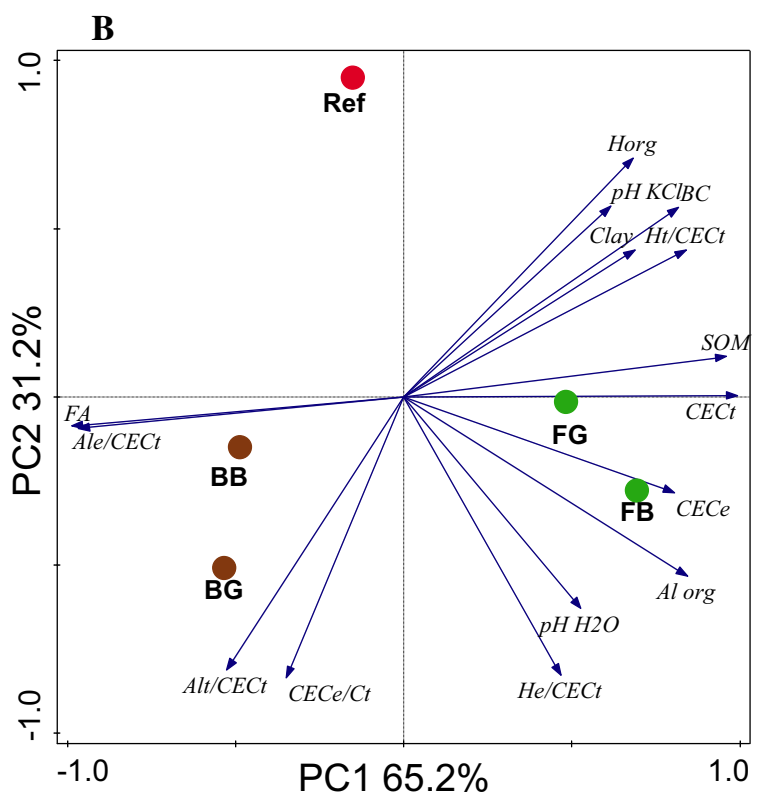

total cation exchange capacity $\left(\mathrm{CEC}_{\mathrm{t}}\right)$, effective cation exchange capacity $\left(\mathrm{CEC}_{\mathrm{e}}\right)$, share of exchangeable hydrogen and aluminium in total cation exchange capacity $\left(\mathrm{H}_{\mathrm{e}} / \mathrm{CEC}_{\mathrm{t}}\right.$ and $\mathrm{Al}_{\mathrm{e}} / \mathrm{CEC}_{\mathrm{t}}$ ), share of total hydrogen and total aluminium in total cation exchange capacity $\left(\mathrm{H}_{\mathrm{t}} / \mathrm{CEC}_{\mathrm{t}}, \mathrm{Al}_{\mathrm{t}} / \mathrm{CEC}_{\mathrm{t}}\right.$, ratio of effective cation exchange to total carbon $\left(\mathrm{CEC}_{\mathrm{e}} / \mathrm{C}_{\mathrm{t}}\right)$

even small changes in clay content, which in our study resulted from the local mud intercalations in magurian sandstones, may modify the cation exchange properties that influence of Al solubility.

Sorption properties are formed by organic and/or mineral soil colloids and the difference in the role of these two components is well seen in the PCA analysis when the Ref soils were included. A major factor PC1, explaining $65.2 \%$ of variance divided the studied soils 
according to understory effect, setting Ref soil properties in between bilberry and fern soils (a little bit closer to bilberry than fern). A second factor PC2 (31.2\% of variance) indicated differences in the sorption complex structure resulting from the stronger effect of spruce needles and/or the share of mineral colloids (inherited from the parent material) in forming sorption properties of studied soils. This factor clearly differentiated Ref soils from bilberry and fern soils, indicating that in the case of a lack of an understory dominating effect (Ref soils), mineral colloids played a more important role in the formation of ion exchangeable properties in A or AE horizons of studied forest soils (Fig. 3b). For this reason as shown in Fig. 3b (with Ref soils included), BC was not as strongly correlated with SOM, as was the case without Ref soils included, shown in Fig. 3a.

\section{Role of organic matter (SOM) in cation binding}

Despite the variability of the stands, both $\mathrm{CEC}_{\mathrm{t}}$ and $\mathrm{CEC}_{\mathrm{e}}$ were strongly correlated with SOM, indicating that the organic matter was an important source of cation exchange capacity, and much less correlated with the clay fraction (Fig. 4a-d). A strong association of $\mathrm{CEC}_{\mathrm{t}}$ with SOM was suggested by a high correlation coefficient and a small intercept $\left(0.204 \mathrm{cmol}_{\mathrm{c}}\right.$ $\mathrm{kg}^{-1}$ soil) of the linear relationship between SOM and $\mathrm{CEC}_{\mathrm{t}}(\mathrm{r}=0.7341, \mathrm{n}=130$, all sites; Fig. 4a). Regression analysis of $\mathrm{CEC}_{\mathrm{e}}$ as a function of SOM also showed a significant correlation $(r=0.6073 n=130$, all sites; Fig. 4b). However, the gradient of the relations between $\mathrm{CEC}_{\mathrm{e}}$ and $\mathrm{SOM}$ varied among both the sites and understory cover. $\mathrm{CEC}_{\mathrm{e}} / \mathrm{SOM}$ correlations were significant for both bilberry soils $(\mathrm{r}=0.524$ for BG and $r=0.592$ for BB), for fern soils ( $r=0.417$ and $r=0.670$, for FG and FB, respectively) and for Ref soils, $(\mathrm{r}=0.6153$ at $\mathrm{p}<0.05)$.

The relationship between $\mathrm{CEC}_{t}$ and SOM was stronger than for $\mathrm{CEC}_{\mathrm{e}}$ and $\mathrm{SOM}$. The smaller intercept in the $\mathrm{CEC}_{\mathrm{t}}$ versus SOM regression indicates that factors other than SOM probably contribute little to $\mathrm{CEC}_{\mathrm{t}}$. According to Johnson (2002), the vegetation determines $\mathrm{CEC}_{\mathrm{e}} / \mathrm{SOM}$ relations in soils when the organic matter is the principal source of exchange sites. The quality of SOM is influenced by both living plants and plant residues. Living plants release organic acids to the soil in root exudates and leaf washings (Huang 1988) while dead plants leaves residues of various susceptibility to decomposition (Ciarkowska 2017; Kraus et al. 2003). SOM accumulated in soils under bilberry contained more fulvic acids and thus less humic acids, than SOM in soils under alpine lady fern soils. Litter of Vaccinium species decomposes slowly because of their woody texture and high content of lignin and condensed tannins; which, according to Ciarkowska and Miechówka (2017), results in a lower decomposition and the formation of humus with a high fulvic acid content.

As FAs often contain 2 to 3 times more carboxyl groups than the HAs isolated from the same soil (Tan 2005), they complex Al mainly through electrostatic attraction, which allows $\mathrm{Al}$ to be more easily be leached down the profile. In contrast, the binding of metals by HAs is predominantly through coordination bonds which are more stable. In this way HAs, by chelating metal ions and decreasing their solubility, play an important role in reducing a toxic effect of aluminium to plants and further to humans and animals (Abreu et al. 2003; Huang 1988). For that reason accumulation of SOM in upper soil horizons in alpine lady fern soils as well as in Ref soils resulted in a decrease in the levels of exchangeable $\mathrm{Al}$ and $\mathrm{H}$ together with the increase of organic forms $\left(\mathrm{Al}_{\text {org }}\right.$ and $\mathrm{H}_{\text {org }}$ ) bound to SOM in non-exchangeable way compared to bilberry soils. As a consequence, in A horizons of soils under alpine lady fern and Ref soils the solubility of organic matter was lower while the amount of SOM and $\mathrm{pH}$ values were higher than in soils under bilberry.

Our findings are consistent with results of Tủma et al. (2012), who noted an effect of fern cover on lowering soil acidity and cation leaching in acid soils. At the end of a five-year experiment examining the effect of alpine lady fern on soils of deforested areas, they found that in soils with fern cover $\mathrm{Mg}^{2+}$ and $\mathrm{K}^{+}$ contents increased when compared to bare soil. This effect was due to the fern's ability to accumulate nutrients in living material, in dead plant biomass and especially in below-ground biomass which resulted in soil enrichment with nutrients. In our study, Ref soils were forest soils rather than bare ground. Thus, the effect of alpine lady fern was a bit masked by the influence of trees, though we could still observe that $\mathrm{pH}$ and $\mathrm{BC}$ values in fern soils were similar or even higher than in Ref soils. 
A

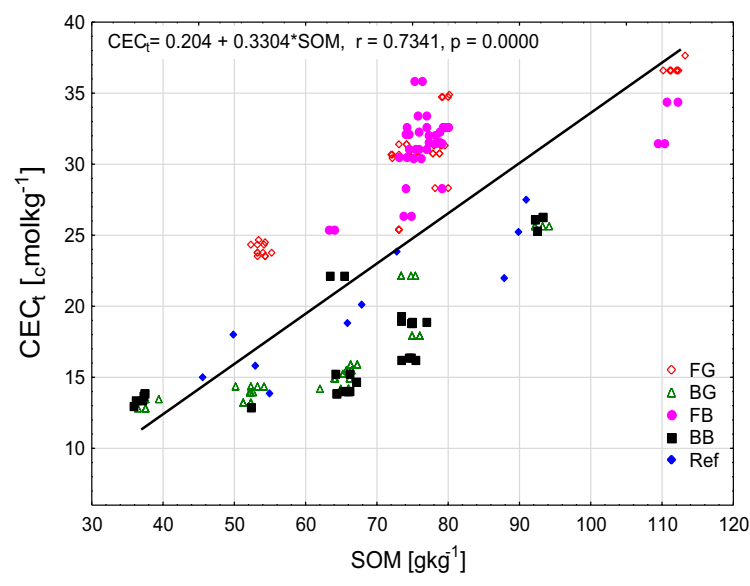

C

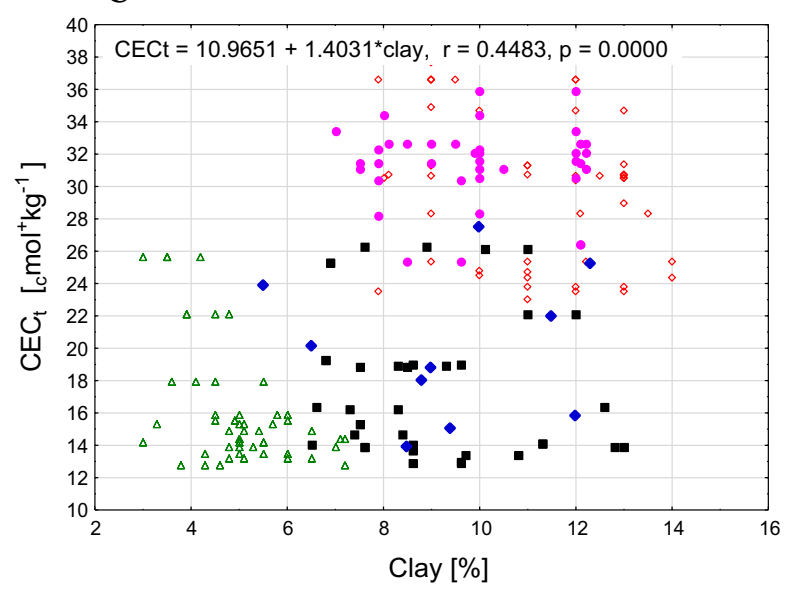

Fig. 4 a, b Relationships between total $\left(\mathrm{CEC}_{\mathrm{t}}\right)$ and effective cation exchange capacity $\left(\mathrm{CEC}_{\mathrm{e}}\right)$ and soil organic matter $(\mathrm{SOM}) ; \mathbf{c}, \mathbf{d}$ relationships between total $\left(\mathrm{CEC}_{\mathrm{t}}\right)$ and effective

Aluminium behaviour in forest soils under bilberry and Alpine lady fern in the understory

The $\mathrm{pH}_{\text {threshold }}$ is assumed to be a good predictor for the $\mathrm{pH}$ at which maximum $\mathrm{Al}$ bonding (both $\mathrm{Al}_{\mathrm{e}}$ and $\mathrm{Al}_{\text {org }}$ ) occurs (Mueller et al. 2012). At pH below $\mathrm{pH}_{\text {threshold, }}$, a further dissolution of $\mathrm{Al}(\mathrm{OH})_{3}$, if still present, is kinetically constrained and further inputs of strong acids are neutralized by decomplexation of organically bound Al (Gruba and Mulder 2015). The significantly higher $\mathrm{pH}_{\text {threshold }}$ observed in bilberry soils than in other soils means that the dominant buffering process in soil changes from $\mathrm{Al}(\mathrm{OH})_{3}$ to organically bound $\mathrm{Al}$ at a higher $\mathrm{pH}_{\mathrm{H} 2 \mathrm{O}}$ than in fern and Ref soils.

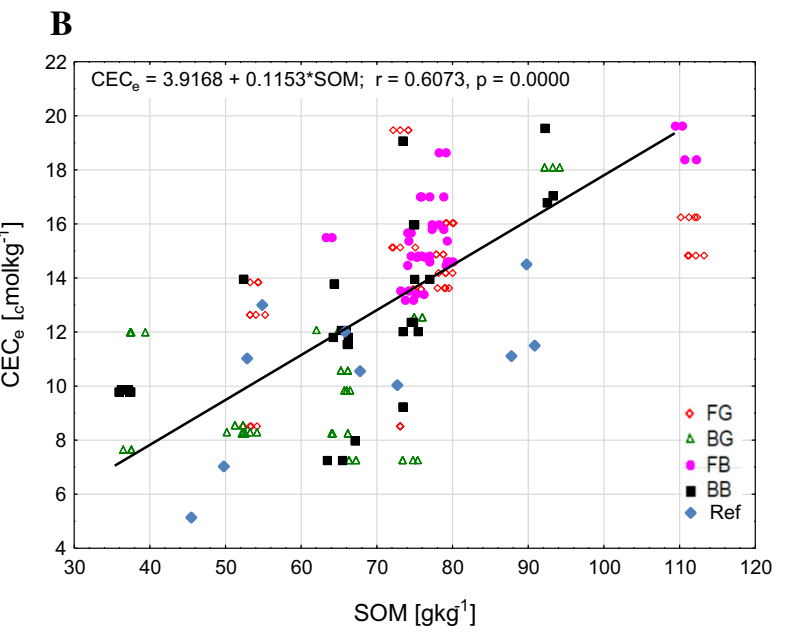

D

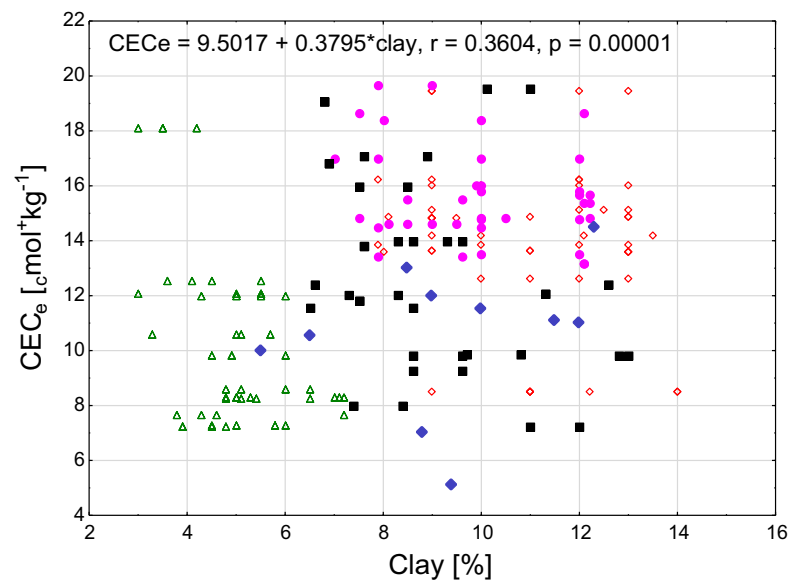

cation exchange capacity $\left(\mathrm{CEC}_{\mathrm{e}}\right)$ and clay. Lines are functional relations and are displayed in cases of strong statistical correlations

All of the studied soils had similar $\mathrm{pH}_{\mathrm{H} 2 \mathrm{O}}$, but differed in $\mathrm{pH}_{\text {tresholds; }}$ in fern and Ref soils the difference between $\mathrm{pH}_{\text {threshold }}$ and $\mathrm{pH}_{\mathrm{H} 2 \mathrm{O}}(\Delta \mathrm{pH})$ was smaller than in bilberry soils. Thus, in bilberry soils decomplexation of organically bound Al was more advanced than in other soils. In fern soils the $\mathrm{Al}_{\text {org }} / \mathrm{H}_{\text {org }}$ ratio was 0.6 , in Ref soils it was 0.5 while in bilberry soils this ratio was 0.4 (Fig. 2). (Skyllberg et al. 2001) observed that an increase in the $\mathrm{Al}_{\text {org }} / \mathrm{H}_{\text {org }}$ ratio results in an increased $\mathrm{pH}$ value, which he explained by a weaker acidity of the organic Alcomplex, as compared to the protonated forms of the same organic acid sites. Similarly Wesselink et al. (1996) observed that a $\mathrm{pH}$ decrease of 0.1 to $0.3 \mathrm{pH}$ units in the $\mathrm{pH}$ range 3.2 to 3.6 in acidic Dutch soils 
Table 2 Parameter estimates for Bloom and Grigal equation. Estimates were derived from gradients and intercepts of relations between $\mathrm{pH}_{\mathrm{KCl}}$ and base saturation $\left(\mathrm{BS}_{\mathrm{e}}\right)$ or $\mathrm{pH}_{\mathrm{KCl}}$ and base saturation with exchangeable $\mathrm{Al}$ included $\left(\mathrm{BS}_{\mathrm{e}}^{*}\right)$

\begin{tabular}{|c|c|c|c|c|c|c|}
\hline \multirow[t]{2}{*}{ Data set } & \multicolumn{3}{|c|}{ Equation $\mathrm{BS}_{\mathrm{e}}$} & \multicolumn{3}{|c|}{ Equation $\mathrm{BS}_{\mathrm{e}}^{*}$} \\
\hline & $\mathrm{pK}_{\mathrm{app}}$ & $\mathrm{n}$ & $\mathrm{r}$ & $\mathrm{pK}_{\mathrm{app}}$ & $\mathrm{n}$ & $\mathrm{r}$ \\
\hline Ref & 2.287 & -0.714 & -0.296 & 2.241 & 0.973 & $0.800^{*}$ \\
\hline FG & 6.035 & 2.710 & $0.675^{*}$ & 2.753 & 0.885 & 0.438 \\
\hline BG & 2.159 & -0.524 & -0.373 & 2.677 & 0.122 & $0.604 *$ \\
\hline FB & 4.876 & 1.825 & $0.657 *$ & 2.810 & 0.354 & 0.232 \\
\hline $\mathrm{BB}$ & 3.716 & 0.642 & 0.463 & 2.680 & 0.212 & $0.930 *$ \\
\hline
\end{tabular}

$\mathrm{N}=30$ for $\mathrm{FG}, \mathrm{BG}, \mathrm{FB}$ and $\mathrm{BB} . \mathrm{N}=10$ for Ref

was connected with a decreasing $\mathrm{Al}$ saturation of SOM.

To test the understory communities-related cation binding properties of soil organic matter we applied the Henderson-Hasselbalch equation with the modification of Bloom and Grigal (1985) (Eq. 2). In fern soils, positive correlations were observed between $\mathrm{pH}$ and $\log \left(\mathrm{BS}_{\mathrm{e}} /\left(1-\mathrm{BS}_{\mathrm{e}}\right)\right)$ for both FG and FB soils, while in bilberry soils these values were not correlated regardless of the location. Skyllberg (1999, 2001), Johnson (2002) and Gruba and Mulder (2008) have also observed negative or insignificant correlations between base saturation and $\mathrm{pH}$, attributing their findings to the non-acidic behaviour of $\mathrm{Al}$.

To explain Al behaviour, Johnson (2002) and Ross et al. (2008) proposed a revised form of Eq. (2), i.e. $\mathrm{pH}=\mathrm{pK}_{\mathrm{app}}+\mathrm{n} \log \left[\mathrm{BS}_{\mathrm{e}}^{*} /\left(1-\mathrm{BS}_{\mathrm{e}}^{*}\right)\right]$, where $\mathrm{BS}_{\mathrm{e}}^{*}$ is the base saturation calculated with $\mathrm{Al}$ included. When this equation is applied, significant positive correlations were observed between $\mathrm{pH}$ and $\log \left[\mathrm{BS}_{\mathrm{e}}^{*} /\right.$ $\left.\left(1-\mathrm{BS}_{\mathrm{e}}^{*}\right)\right]$ in bilberry soils (independently of the location) (Table 2). Furthermore, the estimated values of the parameters $\mathrm{pK}_{\mathrm{app}}$ and $\mathrm{n}$ in the equations were quite consistent among the alpine lady fern data sets when Eq. 2 was applied, while for bilberry they were consistent when the modified Eq. 2 was used.

Effectively modelled relationships between $\mathrm{pH}$ and basic cation saturation with $\mathrm{Al}$ included for bilberry soils supported the hypothesis that in acidic forest soils under certain conditions, such as advanced podsolization processes, Al behaves like a base cation. Similarly to bilberry soils, the alkaline character of $\mathrm{Al}$ occurred also in reference soils, expressed by a positive correlation between $\mathrm{pH}_{\mathrm{KCl}}$ and $\mathrm{BS}_{\mathrm{e}}$ when $\mathrm{Al}_{\mathrm{e}}$ was included in $\mathrm{BS}_{\mathrm{e}}$. This means that in acidic soils under spruce forest stands, bilberry presence did not influence $\mathrm{Al}$ behaviour, while alpine lady fern as main understory species changed $\mathrm{Al}$ properties.

\section{Conclusions}

For nearly all of the parameters investigated in this study both bilberry and fern soils were different than the reference soils which in many cases were intermediate. Reference soils showed that both understories (alpine lady fern or bilberry) of the spruce forest affected soil chemistry, in different ways. High correlations between soil organic matter and both total and effective cation exchange capacity, showed that SOM was the main source of CEC in humus horizons of acidic forest soils. In soils with bilberry, a decrease of organic forms of $\mathrm{H}$ and $\mathrm{Al}$ bound to SOM in a nonexchangeable way was observed when compared to reference soils and soils under alpine lady fern. Moreover, in fern soils, Al behaved like an acid cation, in contrast to reference and bilberry soils, where the advanced podsolization processes occurred and $\mathrm{Al}$ behaved as a basic cation. A dominance of Alpine lady fern in the understory in spruce forests has environmental significance through reducing solubility of $\mathrm{Al}$, preventing its leaching and decreasing its potential toxicity. In our work we showed that the influence of the understory on soils is significant due to its abundance and can greatly impact soil biogeochemical cycles.

Acknowledgements This Research was financed by the Ministry of Science and Higher Education of the Republic of Poland (DS-3109/IGiA/17). 
Open Access This article is distributed under the terms of the Creative Commons Attribution 4.0 International License (http:// creativecommons.org/licenses/by/4.0/), which permits unrestricted use, distribution, and reproduction in any medium, provided you give appropriate credit to the original author(s) and the source, provide a link to the Creative Commons license, and indicate if changes were made.

\section{References}

Abreu CH Jr, Muraoka T, Lavorante AF (2003) Relationship between acidity and chemical properties of Brazilian soils. Sci Agric 60(2):337-343

Arbestain MC, Barreal ME, Mourenza C, Álvarez E, Kidd P, Macías F (2003) Rhizosphere chemistry in acid forest soils that differ in their degree of Al-saturation of organic matter. Soil Sci 168(4):267-279

Berggren D, Mulder J (1995) The role of organic matter in controlling aluminium solubility in acidic mineral soils horizons. Geochim Cosmochim Acta 59:4167-4180

Binkley D, Giardina C (1998) Why do tree species affect soils? The warp and woof of tree-soil interactions. Biogeochemistry 42(1-2):89-106

Blaser P, Walthert L, Zimmermann S, Pannatier EG, Luster J (2008) Classification schemes for the acidity, base saturation, and acidification status of forest soils in Switzerland. J Plant Nutr Soil Sci 171(2):163-170

Bloom PR, Grigal DF (1985) Modelling soil response to acid deposition in nonsulfate adsorbing soils. J Environ Qual 14:489-495

Calderoni G, Schnitzer M (1984) Effects of age on the chemical structure of paleosol humic acids and fulvic acids. Geochim Cosmochim Acta 48:2045-2051

Ciarkowska K (2017) Organic matter transformation and porosity development in non-reclaimed mining soils of different ages and vegetation covers: a field study of soils of the zinc and lead ore area in SE Poland. J Soils Sediments 17:2066-2079. https://doi.org/10.1007/s11368-0171678-4

Ciarkowska K, Miechówka A (2017) The role of bilberry and Alpine lady-fern in soil formation within the Carpathian subalpine spruce forest stands. Geoderma 305:162-172. https://doi.org/10.1016/j.geoderma.2017.06.004

Cieszkowski M (2006) Scientific geological attractions of Gorce National Park and its surroundings. Ochrona Beskidów Zachodnich 1:45-57 (in Polish)

Gruba P, Mulder J (2008) Relationship between aluminium in soils and soil water in mineral horizons of a range of acid forest soils. Soil Sci Soc Am J 72(4):1150-1157. https:// doi.org/10.2136/sssaj2007.0041

Gruba P, Mulder J (2015) Tree species affect cation exchange capacity (CEC) and cation binding properties of organic matter in acid forest soils. Sci Total Environ 511:655-662. https://doi.org/10.1016/j.scitotenv.2015.01.013

Gruba P, Mulder J, Brożek S (2013) Modelling the pH dependency of dissolved calcium and aluminium in $\mathrm{O}$, A and $\mathrm{B}$ horizons of acid forest soils. Geoderma 206:85-91. https:// doi.org/10.1016/j.geoderma.2013.04.036
Huang PM (1988) Ionic factors affecting aluminium transformation and the impact on soil and environmental sciences. In: Steward BA (ed) Advanced in soil science. Springer, New York, pp 1-63

IUSS Working Group WRB (2015) World Reference Base for soil resources 2014. International soil classification system for naming soils and creating legends for soil maps. Update 2015. World Soil Resources Report No. 106. FAO, Rome, p 192

James J, Littke K, Bonassi T, Harrison R (2016) Exchangeable cations in deep forest soils: separating climate and chemical controls on spatial and vertical distribution and cycling. Geoderma 279:109-121. https://doi.org/10.1016/ j.geoderma.2016.05.022

Johnson CE (2002) Cation exchange properties of acid forest soils of the northeastern USA. Eur J Soil Sci 50:95-106

Kraus TEC, Dahlgren RA, Zasoski RJ (2003) Tannins in nutrient dynamics of forest ecosystems - a review. Plant Soil 256:41-66

Li W, Chris E, Johnson CE (2016) Relationships among pH, aluminium solubility and aluminium complexation with organic matter in acid forest soils of the Northeastern United States. Geoderma 271:234-242. https://doi.org/10. 1016/j.geoderma.2016.02.030

Loch J (2002) The subalpine spruce forest of the Gorce National Park-a state and dynamics. Problemy Zagospodarowania Ziem Górskich 48:185-193

Miczyński J (2006) Climate. In: Różański W (ed) 25 years of natural and cultural heritage of the Gorce region. Gorce National Park, Poręba Wielka, pp 35-37 (in Polish)

Mueller KE, Eissenstat DM, Hobbie SE, Oleksyn J, Jagodzinski AM, Reich PB, Chadwick OA, Chorover J (2012) Tree species effects on coupled cycles of carbon, nitrogen, and acidity in mineral soils at a common garden experiment. Biogeochemistry 111:601-614. https://doi.org/10.1007/ s10533-011-9695-7

Mulder J, DeWit H, Boonen H, Bakken L (2001) Increased levels of aluminium in forest soils: effects on the stores of soil organic carbon. Water Air Soil Pollut 130:989-994

Obrębska-Starkel B (2004) The climate of the Babia Góra massif. In: Wołoszyn W, Jaworski A, Szwagrzyk J (ed.). Babia Góra National Park. Natural Monography. Nature Conservation Committee of the Polish Academy of Sciences, Kraków, pp. 137-151 (in Polish)

Ostrowska A, Gawlinski S, Szczubialka Z (1991) Methods of analysis and assessment of soil and plant properties. Manual. Environmental Protection Institute, Warszawa (in Polish)

Parusel J, Kasprowicz M, Holeksa J (2004) Forest and brushwood communities In the Babiogórski National Park. In.: Wołoszyn W, Jaworski A, Szwagrzyk J (eds.), The Nature of the Babia Góra National Park, Monograph, Babia Góra National Park, Nature Conservation Committee of the Polish Academy of Sciences, Kraków, pp. 429-475 (in Polish)

Ross DS, Matschonat G, Skyllberg U (2008) Cation exchange in forest soils: the need for a new perspective. Eur J Soil Sci 59(6):1141-1159

Skyllberg U (1999) pH and solubility of aluminium in acidic forest soils: a consequence of reactions between organic acidity and aluminium alkalinity. Eur J Soil Sci 50:95-106 
Skyllberg U, Raulund-Rasmussen K, Borggaard OK (2001) pH buffering in acidic soils developed under Picea abies and Quercus robur - Effects of soil organic matter, adsorbed cations and soil solution ionic strength. Biogeochemistry 56(1):51-74. https://doi.org/10.1023/A:1011988613449

StatSoft Inc. 2014 Poland. Statistica (data analysis software system), version 12.0. Tulsa

Tan KH (2005) Soil sampling, preparation and analysis. Taylor $\&$ Francis Group, Boca Raton

ter Braak CJF, Smilauer P (2012) Canoco reference manual and user's guide: software for ordination, version 5.0, https:// doi.org/10.1016/j.apsoil.2016.02.012
Tůma I, Fiala K, Záhora J, Holub P (2012) The role of Athyrium distentifolium in reduction of soil acidification and base cation losses due to acid deposition in a deforested mountain area. Plant Soil 354:107-120

Wesselink LG, van Breemen N, Mulder J, Janssen PH (1996) A simple model of soil organic matter complexation to predict the solubility of aluminium in acid forest soils. Eur $\mathrm{J}$ Soil Sci 47:373-384

Publisher's Note Springer Nature remains neutral with regard to jurisdictional claims in published maps and institutional affiliations. 